\title{
Specialist predation on the Caribbean gorgonian Plexaurella spp. by Cyphoma signatum (Gastropoda)
}

\author{
J. L. Ruesink*, C. Drew Harvell \\ Section of Ecology and Systematics, Cornell University, Ithaca, New York 14853, USA
}

\begin{abstract}
The rare marine snail Cyphoma signatum is a trophic specialist on gorgonians Plexaurella spp. A comparative study of this snail species with its generalist congener $C$. gibbosum showed that feeding behavior differs between the 2 species. Feeding by the specialist often damages the polyps and scleratinized matrix of Plexaurella or bares its proteinaceous axis, while the generalist tends to feed primarily on the polyps of Plexaurella. As a result, $C$. signatum ingests more total Plexaurella tissue (including sclerites) and more organic material, though fewer polyps per time, than does C gibbosum. Differences in radular morphology are implicated as the proximal cause of species-specific feeding behavior. The lateral teeth of $C$. signatum are wider and their median teeth have a long central point not present in C. gibbosum, which may enable more extensive wounding of colonies. The feeding behavior of the specialist results in a higher amount of damage to Plexaurella, from which the coral recovers more slowly, as gorgonian regeneration times are inversely proportional to wound depths. Permanent damage to Plexaurella may result when bared proteinaceous axes are fouled by algae or other encrusting organisms. Although the shallow wounds of C. gibbosum are common on Plexaurella, they regenerate within $6 \mathrm{~d}$. Gorgonian censuses at 4 sites showed that high proportions of permanently damaged Plexaurella ( $\geq 50 \%$ permanent damage per colony) were correlated with areas of high $C$. signatum density. In the short term, predation by $C$. signatum appears to increase permanent damage and mortality of Plexaurella. The specialist snail may therefore impose greater selection on the gorgonian than does the generalist.
\end{abstract}

\section{INTRODUCTION}

In coral reef ecosystems, predators often contribute a substantial amount of the injury sustained by coral colonies (Reese 1977, Lasker 1985, Wahle 1985, Harvell \& Suchanek 1987, Lasker et al. 1988). Destruction of individual modules diminishes a colony's feeding ability and reproductive output, and thus reduces fitness without necessarily causing complete mortality (Jackson 1977 , Palumbi \& Jackson 1982). The severity of damage from different partial predators depends on the rates at which modules are destroyed and subsequently regenerate.

The upright, branching gorgonians Plexaurella spp. are prey for 2 closely-related species of tropical marine ovulid. Cyphoma signatum specializes on gorgonians of this genus as its sole food source, while Cyphoma gibbosum feeds on most of the gorgonian genera found

- Present address: Botany School, Downing Street, Cambridge CB2 3EA, England in the Caribbean (Birkeland \& Gregory 1975, Harvell \& Suchanek 1987, Lasker et al. 1988). This study examined predator-prey interactions, concentrating on differences in feeding behavior and prey wounding patterns for the specialist and generalist predators. We examined the specific hypotheses that: (1) C. signatum feeds faster and makes deeper wounds on Plexaurella than its generalist congener; (2) C. signatum has morphological specializations which allow it to ingest the matrix of Plexaurella despite its high sclerite content; (3) predation by C. signatum causes higher rates of permanent damage and colony mortality relative to predation by the generalist.

\section{METHODS}

Research was conducted primarily at the West Indies Laboratory, St. Croix, US Virgin Islands. We collected Cyphoma gibbosum and C. signatum from 4 shallow 


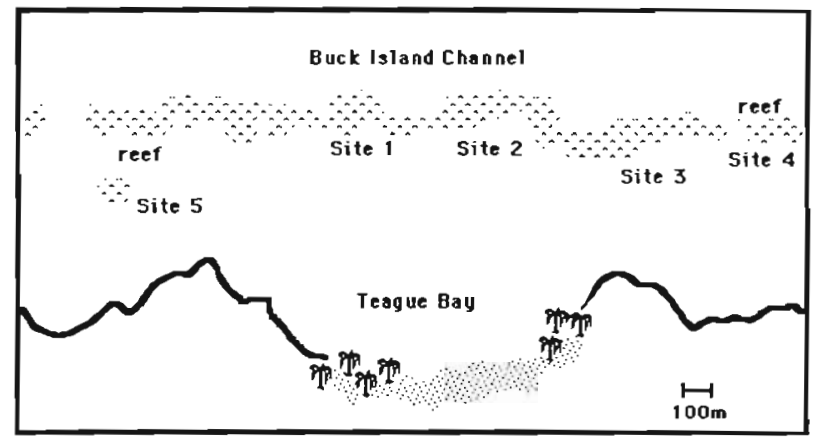

Fig. 1. Census Sites 1 to 4 along Teague Bay back reef and the Site 5 patch reef off the island of St. Croix, US Virgin Islands

$(<5 \mathrm{~m})$ sites haphazardly chosen along Teague Bay back reef (TBBR) and from a nearby patch reef (Fig. 1), spending ca $1 \mathrm{~h}$ at each location. We found $C$. signatum only on colonies of Plexaurella spp., while C. gibbosum was present on several gorgonian genera, including Briareum, Pseudopterogorgia, Plexaura, Pseudoplexaura, Muricea, Gorgonia, and Plexaurella. For each snail collected from Plexaurella, we noted (1) its location on the colony relative to total colony height, and (2) the depth of the wound it had made while feeding. Wound depth was categorized as (1) surface damage involving removal of polyps only, (2) damage to the cortex showing loss of matrix material and sclerites, as well as polyps, and (3) damage baring the proteinaceous axis (Harvell \& Suchanek 1987) (Fig. 2a, b).

We marked individual Cyphoma signatum $(n=18)$ and $C$. gibbosum $(\mathrm{n}=18)$ by etching a series of grooves into their shells, and subsequently released them at the patch reef (Site 5) in early August 1988. Snails on the patch reef were recensused in January 1989.

Feeding behavior. Data from the snail collections were used to establish average location and feeding depth of the 2 species on Plexaurella spp. To examine feeding rates, we used monofilament line to tether Cyphoma gibbosum $(n=7)$ and C. signatum $(n=10)$ to separate, undamaged, haphazardly-chosen Plexaurella colonies in $10 \mathrm{~m}$ of water at Salt River Canyon, St. Croix. After 6 d, the length (L), width (W), and depth (surface, cortex, axis) of all feeding wounds on the
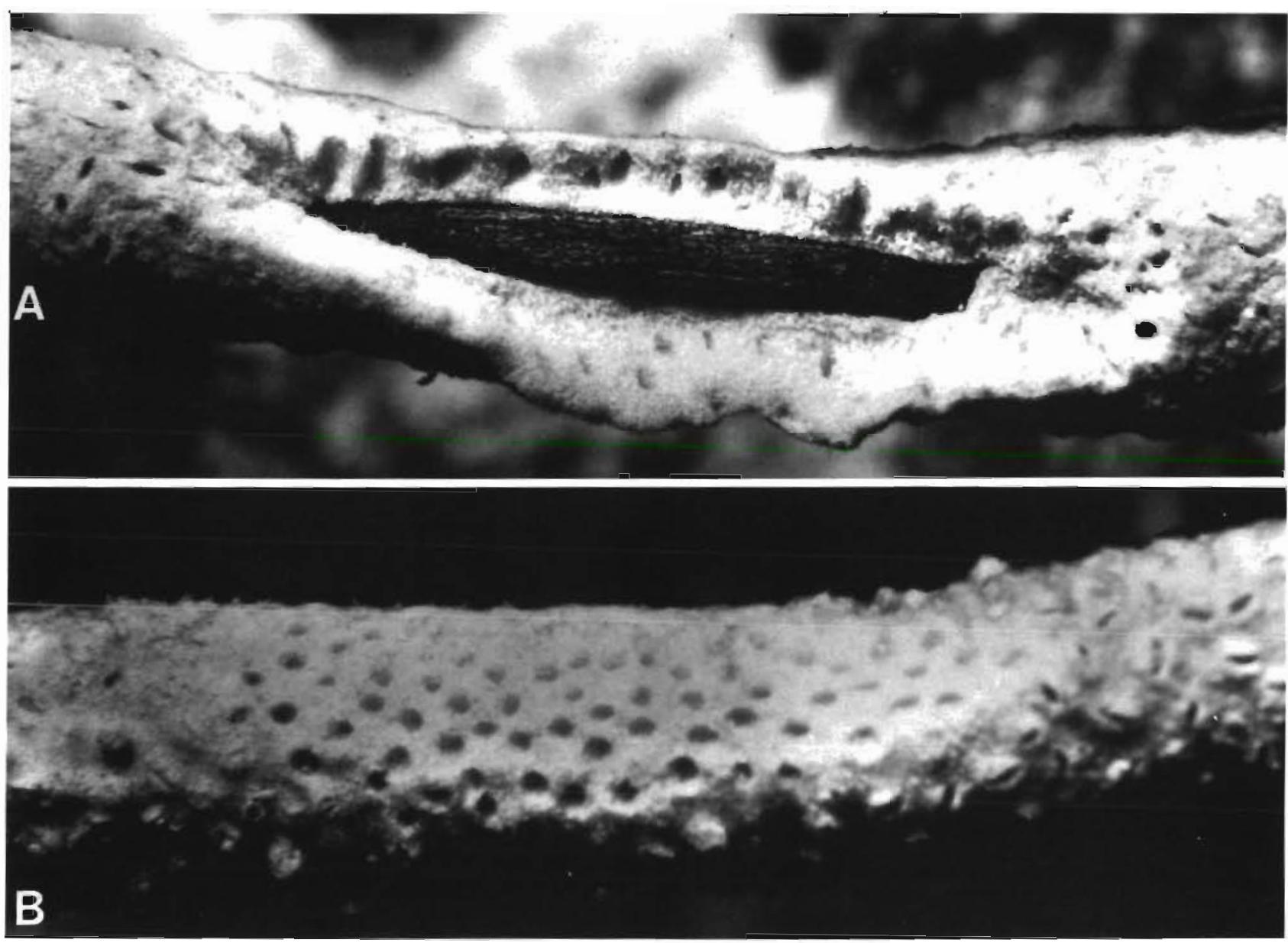

Fig. 2. Plexaurella spp. (a) Wounding by Cyphoma signatum; the scleratinized matrix has been removed, and the proteinaceous axis is visible. (b) Wounding by C. gibhosum, showing removal of polyps only 
colonies were recorded. Area (A) of each surface wound was estimated by the formula: $A=L W$. We found the volume (V) of tissue removed during damage to the cortex using the formula: $V=3 \pi W^{2} L / 32$ (onequarter of the volume of a thick-walled cylinder); for damage to the axis, the formula used was: $V=\pi W^{2} L / 8$ (one-half the volume of a solid cylinder) (Fig. 3).

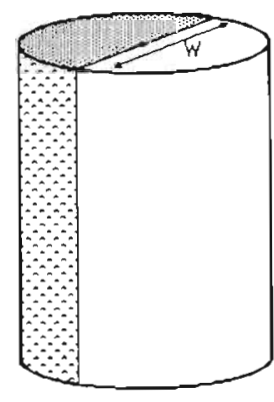

a

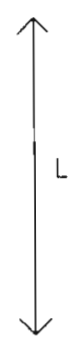

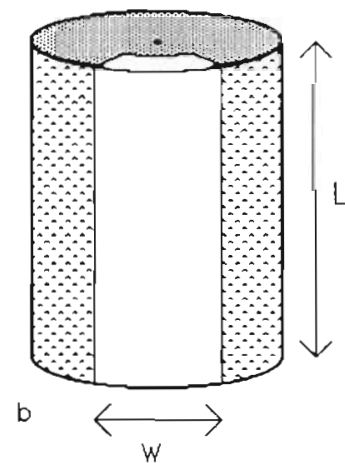

Fig. 3. Plexaurella spp. Diagrammatic representation of a segment of a colony branch showing: (a) how length and width measurements of feeding wounds to the axis were transformed into volume estimates; (b) how length and width measurements of cortex wounds were transformed into volume estimates. (Volume corresponds to the unshaded region)

We were most interested, however, in the weight, not volume, of tissue removed. Dry weight should correspond to the total amount of ingested material, including sclerites, and organic weight should indicate the amount of nutritive tissue available for metabolism. Area or volume of tissue removed during feeding was converted to dry and organic weight using conversion factors established for standard Plexaurella samples. We dried known volumes of Plexaurella from 3 colonies at $60^{\circ} \mathrm{C}$ for $48 \mathrm{~h}$ to establish standard dry weight; organic content was the difference between the dry weight and the weight of the sample after ashing in a muffle furnace at $450^{\circ} \mathrm{C}$ for $2 \mathrm{~h}$ (Harvell \& Suchanek 1987). Standard dry and organic weights were also determined for polyps dissected from a known area of 3 Plexaurella colonies. Standard polyp densities were found from counts of the number of polyps per area of Plexaurella ( $\mathrm{n}=3$ colonies).

Tissue damage to colonies is likely to be influenced not only by the predator's feeding rate, but also by the length of time a partial predator spends on the colony. We assessed residence time using 7 Cyphoma signatum and $11 \mathrm{C}$. gibbosum, which we found naturally on Plexaurella in July 1988; we observed them for $10 \mathrm{~d}$ and recorded their movements among colonies.

Cyphoma morphology. Shell and radula morphology in some gastropods have been found to be related to feeding behavior. Kemp \& Bertness (1984) showed that shell allometry and thickness varied with food availability in individuals of a single gastropod species, indicating that snail feeding and growth rates helped determine shell dimensions. Feeding rates in turn are likely to be influenced by the form of the radula. Radulae dissected from a specialist and a generalist limpet species were morphologically distinct when viewed by Scanning Electron Microscopy (SEM), and differed in the amount of normal force required to scrape various food substrates (Padilla 1985).

Using Vernier calipers (nearest $0.05 \mathrm{~mm}$ ), we measured (1) maximum shell length, (2) maximum shell width at the dorsal transverse ridge, and (3) the thickness of the horizontal ridge at the lip of the shell (Cyphoma signatum: $\mathrm{n}=42 ;$ C. gibbosum: $\mathrm{n}=58$ ). The thickened shell lips present on all specimens indicated that these were adult snails. Because we had no a priori basis for assigning a dependent variable, we calculated allometric relations among these measurements using functional regression (Jensen 1986).

Radulae from 2 specimens of each snail species were viewed using a SEM. They were prepared by dissection from snails preserved in $70 \%$ ethanol and boiled in water for 5 to $10 \mathrm{~min}$. Residual organic tissue was cleared by soaking in bleach. Radulae were rinsed in water and dehydrated by submersion in 2,2-dimethoxypropane for about $30 \mathrm{~s}$ (D. K. Padilla pers. comm.). A gold-palladium coating was applied to all specimens to reduce charging. Specimens were viewed with an AMR-1000A SEM (Cornell University).

Damage to Plexaurella. Permanent damage to Plexaurella spp. depends both on the feeding behavior of its predator and the colony's ability to regenerate. To assess recovery ability, we artificially wounded 6 previously undamaged Plexaurella colonies and observed regeneration over $10 \mathrm{~d}$. Each colony received three $1 \times 5 \mathrm{~cm}$ wounds, on separate branches, corresponding to surface, cortex, and axis damage.

In gorgonians, incomplete regeneration can result in a bare or algal-covered proteinaceous axis. We examined between 100 and 170 gorgonians for permanent damage at Sites 1 to 4 along TBBR, where we had previously collected snails and thus had an estimate of Cyphoma spp. density. We assessed the percentage of tissue missing from each gorgonian colony in $5 \%$ increments from 0 to $10 \%$ and from 90 to $100 \%$, and in $10 \%$ increments otherwise. A 3-way William's G-test was used to test whether increased damage to Plexaurella was associated with sites of high C. signatum density (Sokal \& Rohlf 1981).

\section{RESULTS}

All of the 47 Cyphoma signatum found during this study were collected from gorgonians of the genus Plexaurella. Though the Plexaurella genus is easily 
identifiable in the field, species are difficult to separate. Bayer (1961) recognizes 6 species of Plexaurella, based on differences in colony and sclerite morphology. At least 2 of these species, Plexaurella grisea and $P$. dichotoma, were present on TBBR; $C$. signatum was observed to feed on both under natural conditions. $C$. signatum comprised ca $15 \%$ of the total number of Cyphoma of both species; their densities, however, ranged from quite low ( $\leq 3$ per 1 h collecting dive) at Sites 1 and 2 , to high ( $\geq 12$ per $1 \mathrm{~h}$ collecting dive) at Sites 4 and 5 .

\section{Feeding behavior}

Damage from predation by Cyphoma gibbosum consisted primarily of shallow, surface wounds, while $C$. signatum often wounded the cortex or bared the proteinaceous axis of Plexaurella. C. signatum was significantly more likely to inflict deep wounds, damaging the matrix of Plexaurella (sub-surface damage), than was $C$. gibbosum ( $\chi^{2}$ test: $\mathrm{p}<0.01$ ) (Table 1 ).

Table 1. Plexaurella spp. Number of surface and subsurface (cortex and axis) wounds made by Cyphoma gibbosum and C. signatum

\begin{tabular}{|lcc|}
\hline \multirow{2}{*}{ Wound type } & \multicolumn{2}{c|}{ Snail species } \\
& C. gibbosum & C. signatum \\
\hline Surface & 30 & 10 \\
Sub-surface & 4 & 37 \\
\hline
\end{tabular}

Snails of both species were found on average in the central region of Plexaurella colony branches, though the variance was high (Fig. 4). Arc-sine transformed data showed no significant difference in the location

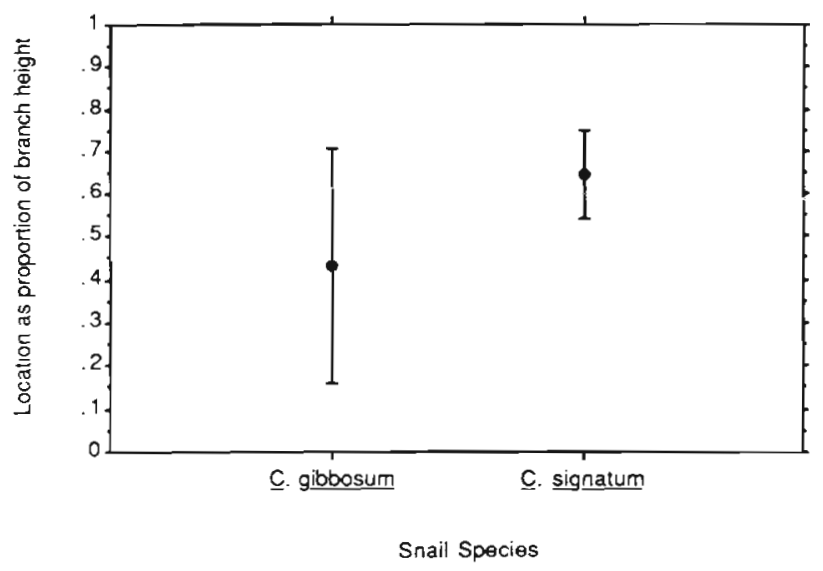

Fig. 4. Cyphoma gibbosum and $C$. signatum. Location on Plexaurella as a proportion of total colony height. Error bars show $95 \%$ confidence intervals. C. gibbosum: $\mathrm{n}=9 ; C$. signatum: $\mathrm{n}=20$ preferred by the 2 snail species (unpaired t-test: $p$ $>0.05)$.

In field trials with tethered snails, the 2 species fed at different rates. All Cyphoma gibbosum used in the trials made only surface wounds, while 9 of $10 \mathrm{C}$. signatum inflicted damage to the cortex. Table 2 shows the standard conversion factors used to convert volume

Table 2. Conversion factors for transforming wound volume to dry weight and organic weight of the material ingested. Results are given as $\mathrm{mg} \mathrm{cm}^{-3}$ for the whole colony ( $\mathrm{n}=3$ ), and as $\mathrm{mg} \mathrm{cm} \mathrm{cm}^{-2}$ for the polyps $(\mathrm{n}=3) .95 \%$ confidence intervals are in parentheses

\begin{tabular}{|lcc|} 
& $\begin{array}{c}\text { Standard } \\
\text { dry wt (mg) }\end{array}$ & $\begin{array}{c}\text { Standard } \\
\text { organic wt (mg) }\end{array}$ \\
\hline $\begin{array}{l}\text { Polyps } \\
\text { Whole colony }\end{array}$ & $\begin{array}{c}5.6( \pm 10.0) \\
( \pm 37)\end{array}$ & $\begin{array}{r}1.5( \pm 0.3) \\
( \pm 2.5)\end{array}$ \\
\hline
\end{tabular}

to mass of tissue ingested. Organic content of the whole colony was low relative to that of the polyps due to the presence of $\mathrm{CaCO}_{3}$ sclerites embedded in the matrix. Mean polyp density was 22.3 polyps $\mathrm{cm}^{-2}( \pm 2.1)$. C signatum ate significantly more than $C$. gibbosum in terms of total tissue (dry wt) and organic material (dry wt - ash wt) during the $6 \mathrm{~d}$ of the experiment (unpaired t-test: $\mathrm{p}<0.01$ ). C. gibbosum, however, ate significantly more polyps (unpaired t-test: $p<0.01$ ) (Fig. 5).

Both Cyphoma species fed for extended periods of time on a single colony and were often found in aggregations. Residence times on Plexaurella spp. for snails observed over $10 \mathrm{~d}$ averaged about $1 \mathrm{wk}$ for both species, though these are likely to be underestimates due to the short observational period. Four of $7 \mathrm{C}$. signatum and 5 of 11 C. gibbosum remained on a single colony during the entire $10 \mathrm{~d}$. Twelve of the $24 \mathrm{C}$. signatum collected in January were found on Plexaurella with one or more other snails.

\section{Cyphoma morphology}

Functional regression (Jensen 1986) of measurements of shell dimensions showed a significant slope for the relation between maximum shell length and maximum shell width in both snail species (Fig. 6). These slopes were also significantly different from each other, indicating that allometric relations differ between the 2 species. Average shell length of $C$. signatum was significantly greater than that of Cyphoma gibbosum (unpaired t-test: $p<0.01$ ). The dorsal transverse ridge, however, as measured by shell thickness at the lip, was significantly more pronounced in C. gibbosum (unpaired t-test: $p<0.01$ ). The recap- 

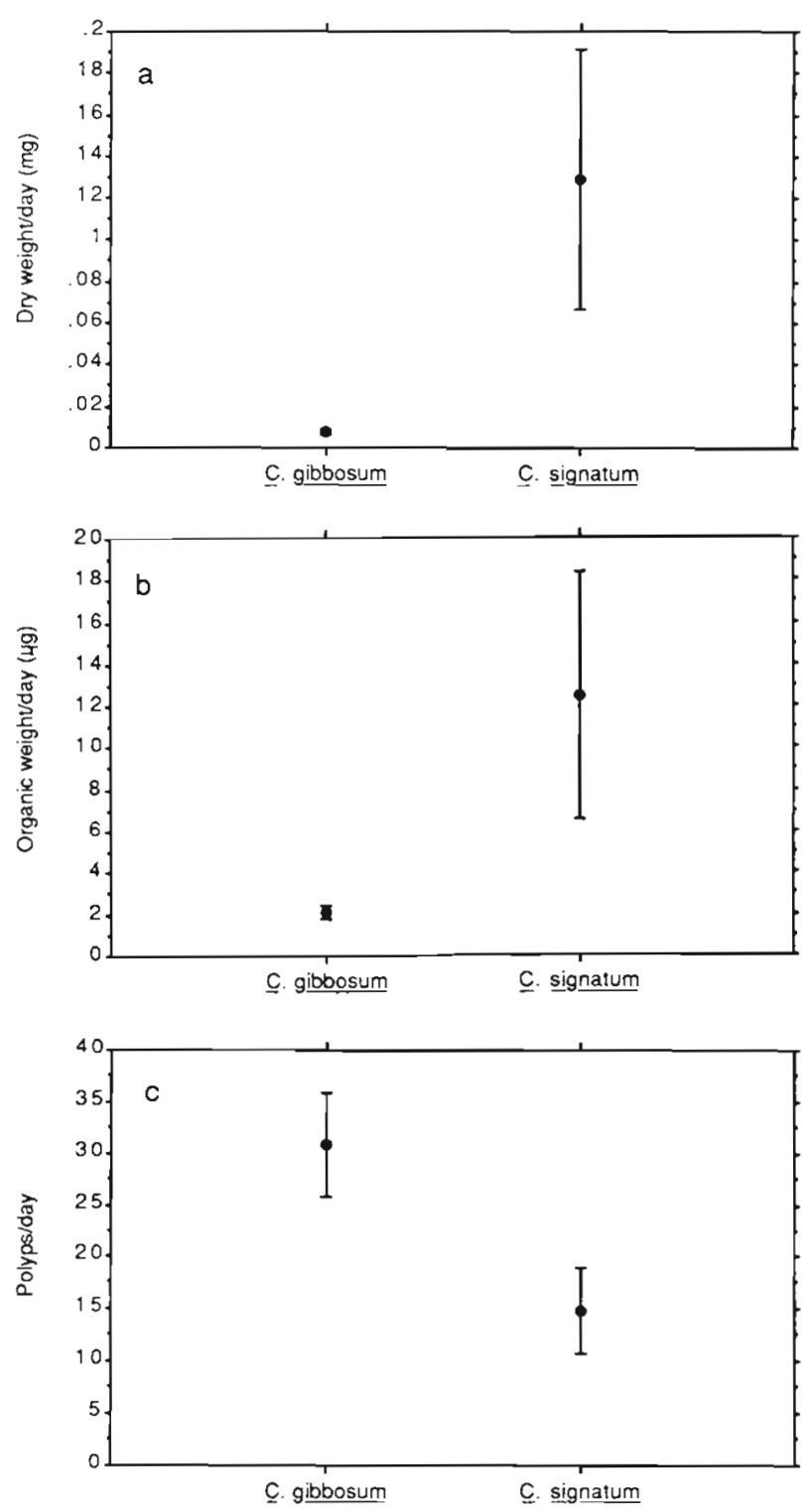

Snail species

Fig. 5. Cyphoma gibbosum and $C$. signatum. Mean dry weight, organic weight, and polyp number ingested over $6 \mathrm{~d}$ while tethered to Plexaurella. Error bars show $95 \%$ confidence intervals. (a) Dry weight of ingested tissue; (b) organic content weight of ingested tissue; (c) polyp number ingested. C. gibbosum: $\mathrm{n}=7 ;$ C. signatum: $\mathrm{n}=10$

ture rate of marked snails left at Site 5 for 6 mo was $38.9 \%$ for C. signatum and $33.3 \%$ for C. gibbosum. It is unlikely that the missing snails migrated away from the patch reef, but, as we found no empty shells, we cannot separate mortality from our inability to find them. No measurable shell growth was recorded in either species after 6 mo, giving further evidence that these were adult snails of full shell size.

Fig. 7 shows scanning electron micrographs of radulae dissected from a $3.2 \mathrm{~cm}$ specimen of each

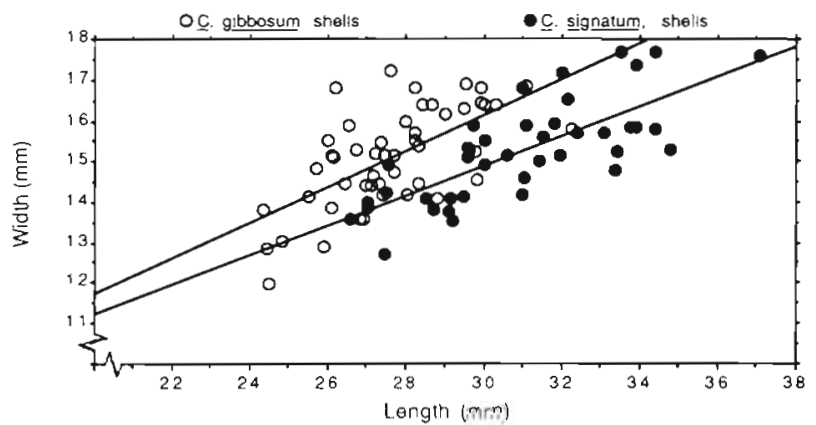

Fig. 6. Cyphoma gibbosum and (- Mnatum. Functional regression between maximum shell length and maximum shell width. $C$. gibbosum: $y=0.4103 x+0.3732, n=58 ; C$. signatum: $\mathrm{y}=0.3670 \mathrm{x}+0.3870, \mathrm{n}=42$. One $C$. signatum specimen was discarded from the analysis due to an extremely unusual width measurement, probably a measuring error
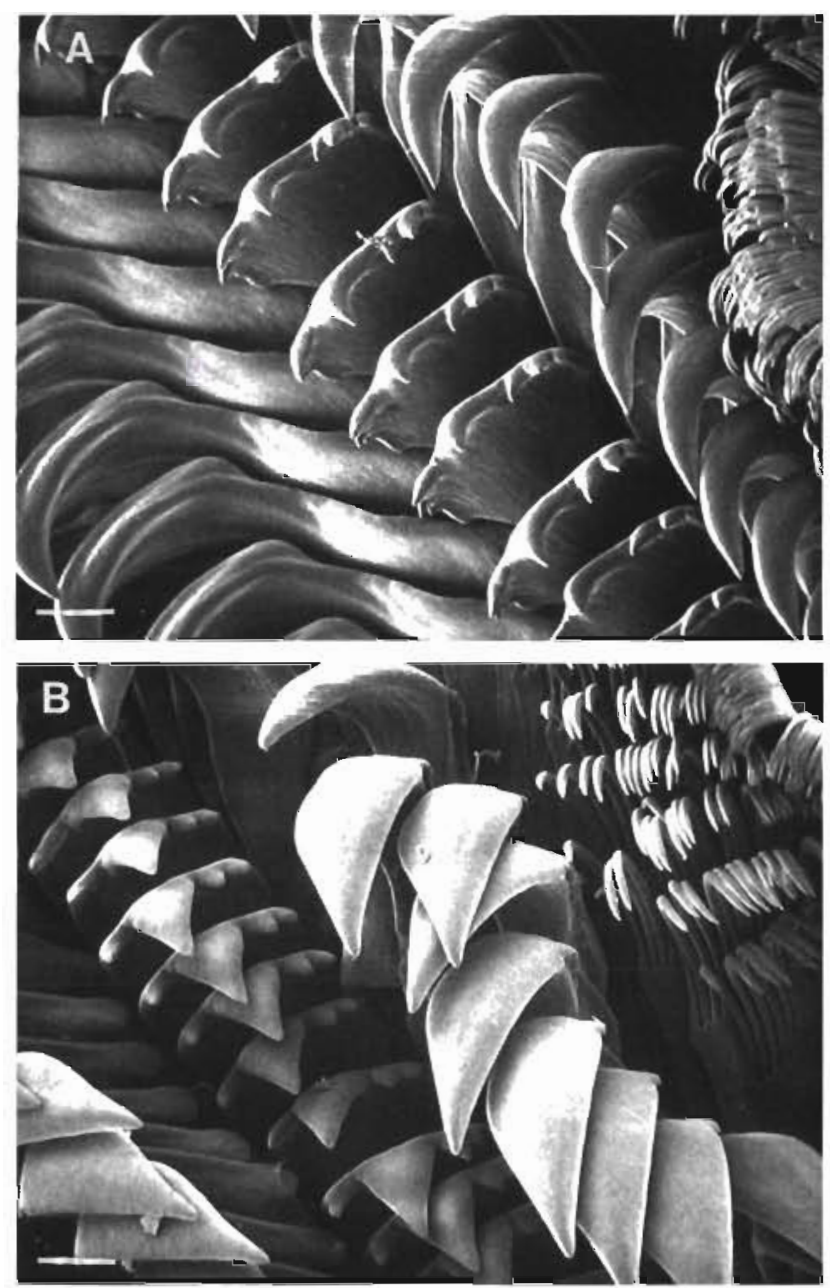

Fig. 7. Scanning electron micrographs of mature teeth of (a) Cyphoma gibbosum radula, (b) C. signatum radula $(150 \times)$. Scale bars $=0.05 \mathrm{~mm}$

species. Other radulae viewed under a dissecting microscope showed similar species-specific morphology; however, only one SEM was taken of each species. The rachidian tooth, which, along with the flanking lateral 
teeth, is responsible for much of the rasping action of the radula (Hickman 1980, Hughes 1986), is slightly wider in Cyphoma gibbosum, but the central point of the tooth is half as long as that of its congener. Relative to C. gibbosum, C. signatum has wider lateral teeth and more rows of teeth per length of radula (Table 3 )

Table 3. Cyphoma gibbosum and C. signatum. Measurements of radulae of single $3.2 \mathrm{~cm}$ specimens, from SEMs at $210 \times$ and $550 \times$ magnification

\begin{tabular}{|lcc|}
\hline & C. gibbosum & C. signatum \\
\hline Rows/length & $14.7 / \mathrm{mm}$ & $23.1 / \mathrm{mm}$ \\
Width & $0.15 \mathrm{~mm}$ & $0.13 \mathrm{~mm}$ \\
$\quad$ Rachidian & $0.04 \mathrm{~mm}$ & $0.07 \mathrm{~mm}$ \\
$\quad$ Lateral & $0.03 \mathrm{~mm}$ & $0.06 \mathrm{~mm}$ \\
Rachidian point &
\end{tabular}

\section{Damage to Plexaurella}

Regeneration of artificial damage to Plexaurella spp. occurred more quickly for shallow than for deep wounds. In all 6 cases, polyps were feeding from regenerated surface wounds within $3 \mathrm{~d}$, although the scars remained visible for at least $10 \mathrm{~d}$. Proteinaceous axes were covered by new matrix material only after $4 \mathrm{~d}$ Regenerating cortex and axis wounds took more than twice as long to produce new feeding polyps as did surface wounds (Table 4).

Table 4. Plexaurella spp. Regeneration from artificial wounds $(1 \times 5 \mathrm{~cm})$ of various depths. $95 \%$ confidence intervals are in parentheses. $n=6$ colonies per wound type

\begin{tabular}{|c|c|c|c|}
\hline \multirow[t]{2}{*}{ Depth of wound } & \multicolumn{3}{|c|}{ Regeneration (d) } \\
\hline & $\begin{array}{l}\text { Axis } \\
\text { recovered }\end{array}$ & $\begin{array}{c}\text { Polyps } \\
\text { feeding }\end{array}$ & $\begin{array}{l}\text { Scar } \\
\text { visible }\end{array}$ \\
\hline Suface & - & $2.5(0.6)$ & $>10$ \\
\hline Cortex & - & $8.7(1.4)$ & $>10$ \\
\hline Axis & $4.2(0.4)$ & $9.5(1.7)$ & $>10$ \\
\hline
\end{tabular}

Plexaurella spp. ranged from 11.0 to $27.5 \%$ of the total gorgonian fauna at the 4 census sites. High proportions of permanently damaged colonies (judged as $\geq 50 \%$ damage/colony) were found at sites with high Cyphoma signatum density (Wilson's G-test: $\mathrm{p}<0.05$ ) (Fig. 8). If this correlation indicates a causal link between C. signatum and Plexaurella damage, it is a striking departure from the relatively small amount of damage usually caused by C. gibbosum (Wahle 1983. Harvell \& Suchanek 1987). At Site 4, where snail density was greatest, 4 of 11 Plexaurella colonies were completely

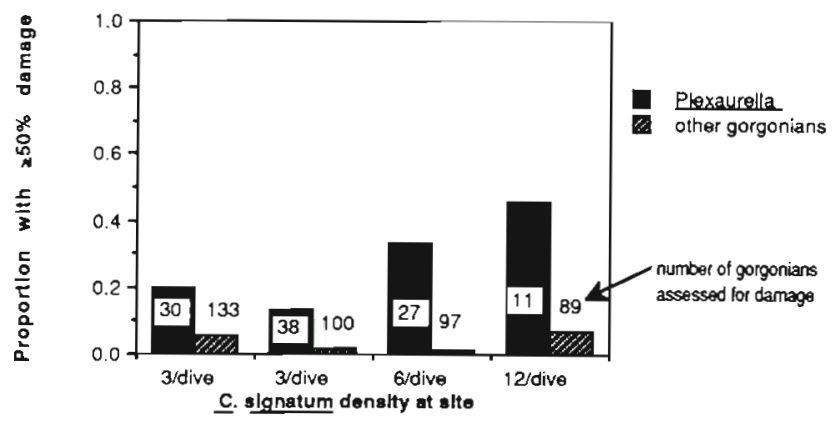

Fig. 8. Proportion of gorgonians (Plexaurella spp. and others) with more than $50 \%$ damage per colony at 4 sites along TBBR. Sites 1 and 2 had approximately equal densities of Cyphoma signatum, while Sites 3 and 4 had higher densities

killed. This site also had the lowest proportion of Plexaurella relative to total gorgonian presence.

\section{DISCUSSION}

\section{Specialization and rarity}

Cyphoma gibbosum is ubiquitous throughout the Caribbean and can be found on most gorgonian genera (Birkeland \& Gregory 1975, Gerhart 1986, Harvell \& Suchanek 1987, Lasker \& Coffroth 1988, Lasker et al. 1988). Though the biology and behavior of C. gibbosum have been well studied (Ghiselin \& Wilson 1966, Bandel 1973, Birkeland \& Gregory 1975, Gerhart 1986, Harvell \& Suchanek 1987, Lasker \& Coffroth 1988), C. signatum has received relatively little attention, in large part because it has been found too rarely for indepth study.

Small numbers of Cyphoma signatum have been found near Union Island in the Grenadines (C. D. Harvell pers, obs.), San Blas, Panama (Lasker \& Coffroth 1988), Puerto Rico (Ghiselin \& Wilson 1966), Jamaica (Wahle 1985), and the Bahamas (J. L. Ruesink \& C. D. Harvell pers obs.), indicating that the species as a whole is widespread throughout the Caribbean. Rarity of $C$. signatum is likely to be a result, primarily, of habitat specificity (Rabinowitz 1981), as the snail appears to be a trophic specialist on Plexaurella spp. and the frequency and location of that gorgonian genus must to some extent determine its predator's distribution. Along TBBR, where Plexaurella comprises between 11 and $29 \%$ of the total gorgonian fauna, $C$. signatum made up some $15 \%$ of all Cyphoma, so that the specialist was found in proportion to the abundance of its food source. However, at Salt River Canyon, a site off St. Croix with similar proportions of Plexaurella, there were no $C$. signatum. Thus, as not all suitable habitats are colonized, the snail also appears to be rare because of restricted local population sizes (Rabinowitz 
1981). At this point, there is insufficient information on the biology of $C$. signatum to know whether these patterns might be due to recruitment or to post-recruitment mortality; neither do we know what may prevent the specialist's utilization of other gorgonian genera.

\section{Differential partial predation}

We assessed feeding behavior in terms of feeding rate, wound depth, residence time, and gregariousness. Although not all specialists are measurably more efficient than generalists at ingesting and metabolizing their food source (Scriber 1983), Cyphoma signatum feeds at a significantly faster rate than its congener by ingesting both more total tissue and more organic material, and by making deeper wounds. While this could be interpreted as a feeding advantage for the specialist, we have been unable to confirm that the intake of more organic material results in any measurable advantage in growth, survival, or reproduction. Although direct growth rate comparisons were impossible, as the collected snails had reached full shell size, differences were detected in the greater length and less pronounced transverse ridge of $C$. signatum. Within a species, relatively thinner, more globose shells indicate a faster growth rate (Kemp \& Bertness 1984, Hughes 1986), but the allometric differences between $C$. signatum and $C$. gibbosum may be of genetic origin, rather than an example of phenotypic plasticity due to growth rate.

It is likely that gorgonian sclerites act as a defence against predation by Cyphoma gibbosum. Harvell \& Suchanek (1987) found that a snail's residence time on a colony was inversely proportional to the percentage of non-organic material in that species, suggesting that high sclerite content deterred feeding (but see Lasker et al. 1988). Feeding experiments using artificial food of carageenan embedded with gorgonian sclerites have shown that sclerite content and size affect food choice in C. gibbosum; in particular, higher proportions of sclerites tend to decrease snail feeding (C. D. Harvell \& J. L. Ruesink unpubl.).

Cyphoma signatum may be able to ingest more tissue and wound more deeply than its congener because of its specialized radula morphology. The relatively wider lateral teeth and the long central point on the rachidian tooth of $C$. signatum may allow the snail to feed despite the presence of densely packed, small $(0.1$ to $0.3 \mathrm{~mm}$ ) sclerites embedded in the matrix of Plexaurella spp. The nutritional content of this matrix material is not high, as sclerites make up over $90 \%$ of the matrix dry weight (as compared to $<50 \%$ in the polyps). However, despite the higher proportion of sclerites in its diet, the specialist ingests more organic material, as well as more total material, than the generalist when feeding on Plexaurella. The ability to feed on all the tissue of this gorgonian would be adaptive if prey were limiting, as it could be for a fairly nonmotile, specialist predator such as C. signatum with a patchy food source.

The residence times we recorded for both snail species ( $>1 \mathrm{wk}$ ) were considerably longer than those reported by Harvell \& Suchanek (1987) for Cyphoma gibbosum $(<2 \mathrm{~d})$; however, in that study $C$. gibbosum were placed on colonies, while we monitored the location of snails already on Plexaurella. Our results are almost certainly underestimated because of the short observational period, but it is uncertain whether they would match the extended periods recorded by Lasker et al. (1988) for C. gibbosum on Pseudoplexaura. Aggregation tendencies in Cyphoma have been reported by several other researchers (Birkeland \& Gregory 1975, Hazlett \& Bush 1982, Gerhart 1986, Lasker \& Coffroth 1988).

\section{The question of coevolution}

Partial predation on colonial organisms decreases feeding and reproductive potential, disrupts colony integration, and may allow overgrowth and death (Jackson \& Palumbi 1979, Palumbi \& Jackson 1982, Wahle 1983, Harvell \& Suchanek 1987). Wahle (1985) established that the main sources of injury to gorgonians were abrasion and predation by Hermodice carunculata and Cyphoma spp., the last of which contributed little to colony damage. C. gibbosum may account for just $4 \%$ of colony mortality in all gorgonians, as colony tissue is generally regenerated more quickly than it is consumed by Cyphoma (Kinzie 1970 in Lang da Silveira \& van't Hof 1977, Birkeland \& Gregory 1975). Although regeneration rates of most gorgonians are rapid (Wahle 1983), deeper wounds recover more slowly (Table 4), longer wounds and repeatedly damaged areas recover more slowly (Lang da Silveira \& van't Hof 1977), and algal settlement on bared axes may completely prevent regrowth (Wahle 1980, Harvell \& Suchanek 1987). The feeding behavior of $C$. signatum, including a high rate of tissue ingestion, deep wounding, long residence time, and a tendency to aggregate, results in extensive damage to Plexaurella colonies. High densities of $C$. signatum are correlated with high levels of permanently damaged Plexaurella colonies.

Closely-associated species have the greatest potential for showing evidence of coevolution (Reese 1977 , Rausher 1988); however, a strict coevolutionary definition requires both specificity and reciprocity of adaptation (Janzen 1980, Futuyma \& Slatkin 1983). While a 
specialized radular morphology may be an adaptation allowing faster feeding by Cyphoma signatum on Plexaurella spp., any coevolutionary response by Plexaurella to this augmented predator ability remains less clear. Selection on Plexaurella, at least under some circumstances, must be intense, as damaged colonies not only would be at a size and reproductive disadvantage, but could, like many of the Site 4 colonies, be completely overgrown by algae and killed. We might expect, then, increases over time in Plexaurella's toxicity to $C$. signatum, sclerite content, and regenerative abilities. The specialist's relative rarity, however, may relegate its effects to local disturbances of Plexaurella populations, preventing $C$. signatum from ever having much effect as a selective agent.

Acknowledgements. Support for this research came from NOAA 183-8314-6650-408 to C.D.H., and from grants to J.L.R. from the Morley Undergraduate Research fund, the Cornell University Honors Program, and Mr Herbert Harvis in memory of his son. We gratefully acknowledge the helpful assistance and good humor of dive buddies Josh Nowlis and Jordan West, and radula expert Dianna Padilla.

\section{LITERATURE CITED}

Bandel, K. (1973). Notes on Cypraea cinerea Gmelin and Cyphoma gibbosum (Linnaeus) from the Caribbean Sea and description of their spawn. Veliger 15: 335-337

Bayer, F. M. (1961). The shallow-water Octocorallia of the West Indian region. Martinus Nijhoff, The Hague

Birkeland, C., Gregory, B. (1975). Foraging behavior and rates of feeding of the gastropod, Cyphoma gibbosum (Linnaeus). Bull. nat. Hist. Mus. Los Ang. Cnty 20: 57-67

Futuyma, D. J., Slatkin, M. (1983). Introduction. In: Futuyma, D. J., Slatkin, M. (eds.) Coevolution. Sinauer Associates, Sunderland, p. 1-13

Gerhart, D. J. (1986). Gregariousness in the gorgonian-eating gastropod Cyphoma gibbosum: tests of several possible causes. Mar Ecol. Prog. Ser. 35: 255-263

Ghiselin, M. T., Wilson, B. R. (1966). On the anatomy, natural history, and reproduction of Cyphoma, a marine prosobranch gastropod. Bull. mar. Sci. 16: 132-141

Harvell, C. D., Suchanek, T H. (1987). Partial predation on tropical gorgonians by Cyphoma gibbosum (Gastropoda). Mar. Ecol. Prog. Ser 38: 37-44

Hazlett, B. A., Bush, C E (1982). Distribution pattern of the Flamingo Tongue Shell (Cyphoma gibbosum) on its gorgonian prey (Briareum asbestinum). Mar. Behav. Physiol. 8 : 305-309

Hickman, C. S. (1980). Gastropod radulae and the assessment of form in evolutionary paleontology. Paleobiol. 6: 276-294

Hughes, R. N. (1986). A functional biology of marine gastropods. JHU Press, Baltimore

Jackson, J. B. C. (1977). Competition on marine hard sub-

This article was submitted to the editor strata: the adaptive significance of solitary and colonial strategies. Am. Nat. 111: 743-767

Jackson, J. B. C., Palumbi, S. R. (1979). Regeneration and partial predation in cryptic coral reef environments: preliminary experiments on sponges and ectoprocts. In: Levi, C., Bourg-Esnault, N. (eds.). Biologie des spongiaires. Centre Nationale de la Recherche, Paris, p. 303-309

Janzen, D. H. (1980). When is it coevolution? Evolution 34 : $611-612$

Jensen, A. L. (1986). Functional regression and correlation analysis. Can. J. Fish. Aquat. Sci. 43: 1742-1745

Kemp, P., Bertness, M. D. (1984). Snail shape and growth rates: evidence for plastic shell allometry in Littorina littorea. Proc natn. Acad. Sci. U.S.A. 81: 811-813

Lang da Silveira, F, van't Hof, T. (1977). Regeneration in Plexaura flexuosa. Bijdr. Dierk. 47: 98-108

Lasker, H. R. (1985). Prey preferences and browsing pressure of the butterflyfish Chaetodon capistratus on Caribbean gorgonians. Mar Ecol. Prog. Ser 21. 213-220

Lasker, H. R., Coffroth, M. A. (1988). Temporal and spatial variability among grazers: variability in the distribution of the gastropod Cyphoma gibbosum on octocorals. Mar Ecol. Prog. Ser. 43: 285-295

Lasker, H. R., Coffroth, M. A., Fitzgerald, L. M. (1988). Foraging patterns of Cyphoma gibbosum on octocorals: the roles of host choice and feeding preference. Biol. Bull. mar. biol Lab., Woods Hole 174: 254-266

Padilia, D. K. (1985). Structural resistance of algae to herbivores: a biomechanical approach. Mar. Biol. 90: 103-109

Palumbi, S. R., Jackson, J. B. C. (1982). Ecology of cryptic coral reef communities. II. Recovery from small disturbance events by encrusting bryozoa: the influence of 'host' species and lesion size. J. exp. mar. Biol. Ecol. 64: 103-115

Rabinowitz, D. (1981). Seven forms of rarity. In: Synge, $H$ (ed.) The biological aspects of rare plant conservation. John Wiley and Sons, Chichester, p. 205-217

Rausher, M. D. (1988). Is coevolution dead? Ecology 69 898-901

Reese, E. S. (1977). Coevolution of corals and coral feeding fishes of the family Chaetodontidae. Proc. Third Intl. Coral Reef Symp. 1: 267-274. Rosenstiel School of Marine and Atmospheric Sciences, University of Miami, Florida

Scriber, J. M. (1983). Evolution of feeding specialization, physiological efficiency, and host races in selected Papilionidae and Saturnidae. In: Denno, R. F., McClure M. S. (eds.) Variable plants and herbivores in natural and managed systems. Academic Press, New York, p. 373-426

Sokal, R. R., Rohlf, F. J. (1981). Biometry. Freeman, San Francisco

Wahle, C. M. (1980). Detection, pursuit, and overgrowth of tropical gorgonians by milleporid hydrocorals: Perseus and Medusa revisited. Science 209: 689-691

Wahle, C. M. (1983). Regeneration of injuries among Jamaican gorgonians: the roles of colony physiology and environment. Biol. Bull. mar. biol. Lab., Woods Hole 165: $778-790$

Wahle, C. M. (1985). Habitat-related patterns of injury and mortality among Jamaican gorgonians. Bull. mar. Sci. 37 : 905-927

Manuscript first received: October 3,1989

Revised version accepted: May 17, 1990 